\title{
Article \\ A Multi-Technique Investigation of the Complex Formation Equilibria between Bis-Deferiprone Derivatives and Oxidovanadium (IV)
}

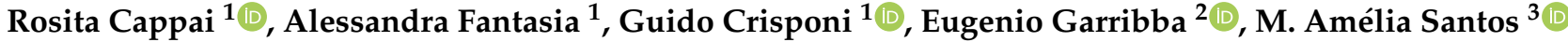 \\ and Valeria Marina Nurchi ${ }^{1, *(\mathbb{D})}$
}

1 Dipartimento di Scienze della Vita e dell'Ambiente, Università di Cagliari, 09042 Monserrato-Cagliari, Italy; cappai@unica.it (R.C.); fantasia.91@hotmail.it (A.F.); crisponi@unica.it (G.C.)

2 Dipartimento di Scienze Mediche, Chirurgiche e Sperimentali, Università di Sassari, Viale San Pietro, 07100 Sassari, Italy; garribba@uniss.it

3 Centro de Quimica Estrutural, Institute of Molecular Sciences, Instituto Superior Técnico, Universidade de Lisboa, Av. Rovisco Pais 1, 1049-001 Lisboa, Portugal; masantos@tecnico.ulisboa.pt

* Correspondence: nurchi@unica.it; Tel.: +39-070-675-4476

check for updates

Citation: Cappai, R.; Fantasia, A.; Crisponi, G.; Garribba, E.; Santos, M.A.; Nurchi, V.M. A

Multi-Technique Investigation of the Complex Formation Equilibria

between Bis-Deferiprone Derivatives and Oxidovanadium (IV). Molecules 2022, 27, 1555. https://doi.org/ 10.3390/molecules 27051555

Academic Editor: Hai-Yang Liu

Received: 27 January 2022

Accepted: 23 February 2022

Published: 25 February 2022

Publisher's Note: MDPI stays neutral with regard to jurisdictional claims in published maps and institutional affiliations.

Copyright: (C) 2022 by the authors. Licensee MDPI, Basel, Switzerland. This article is an open access article distributed under the terms and conditions of the Creative Commons Attribution (CC BY) license (https:// creativecommons.org/licenses/by/ $4.0 /)$.

\begin{abstract}
The increasing biomedical interest in high-stability oxidovanadium(IV) complexes with hydroxypyridinone ligands leads us to investigate the complex formation equilibria of $\mathrm{V}^{\mathrm{IV}} \mathrm{O}^{2+}$ ion with a tetradentate ligand, named KC21, which contains two 3-hydroxy-1,2-dimethylpyridin-4(1H)-one (deferiprone) moieties, and with the simple bidentate ligand that constitutes the basic unit of KC21, for comparison, named L5. These equilibrium studies were conducted with joined potentiometricspectrophotometric titrations, and the results were substantiated with EPR measurements at variable $\mathrm{pH}$ values. This multi-technique study gave evidence of the formation of an extremely stable 1:1 complex between $\mathrm{KC} 21$ and oxidovanadium(IV) at a physiological $\mathrm{pH}$, which could find promising pharmacological applications.
\end{abstract}

Keywords: oxidovanadium (IV); deferiprone; potentiometry; UV spectrophotometry; EPR spectroscopy

\section{Introduction}

Vanadium compounds exhibit in humans different pharmacological activities, such as antiviral, antibacterial, anticancer and antidiabetic properties [1-8]. The historical accumulation of knowledge regarding vanadium antidiabetic activity is presented in an excellent review by Shechter et al. [9]. These authors report that, since its discovery (in 1980), vanadium salts could mimic the action of insulin on hexose uptake and glucose metabolism in rats, and intensive studies were carried out the insulinomimetic effects of new vanadium compounds and on the key mechanisms involved. More recently, research has been focused on the development of new coordinated ligands that could facilitate the absorption of the complexes by the gastro-intestinal tract and their transport in the blood. In this way, vanadium uptake by cells shows a potentially insulinomimetic and also anticancer activity $[1,10,11]$. At the moment, the reference molecules for any new vanadium compound characterized by antidiabetic activity are bis(maltolato)oxidovanadium(IV) (BMOV) and bis(ethylmaltolato)oxidovanadium(IV) (BEOV), with BEOV being the only vanadium compound submitted to clinical trials. Renal problems in some participating patients led to the withdrawal of these trials in phase II $[12,13]$. The antidiabetic properties of other $\mathrm{V}^{\mathrm{IV}}$ compounds have been the focus of a large number of studies. Promising compounds in this regard are those formed by 3-hydroxy-1,2-dimethylpyridin$4(1 H)$-one (deferiprone, DFP) [14]. In particular, the complex $\left[\mathrm{V}^{\mathrm{IV}} \mathrm{O}(\mathrm{DFP})_{2}\right]$ is effective in the release of free fatty acids from isolated rat adipocytes, has better antidiabetic action than inorganic salt $\mathrm{V}^{\mathrm{IV}} \mathrm{OSO}_{4}$ and presents a peculiar insulin-enhancing activity, 
as well as a noteworthy anticancer activity [15]. It shows a high antiproliferative activity against A375 malignant melanoma cells, causing apoptosis and cell cycle blocking. Moreover, it reduces the phosphorylation of ERK by about $80 \%$, causing the deactivation of MAPK pathway in A375 cells, and induces the dephosphorylation of the retinoblastoma protein by $90 \%$ [16]. The complex formation equilibria of DFP with oxidovanadium(IV) $\left(\mathrm{V}^{\mathrm{IV}} \mathrm{O}^{2+}\right)$ ion were already characterized at $25^{\circ} \mathrm{C}$ and $0.2 \mathrm{M} \mathrm{KCl}$ ionic strength by Buglyó et al. [17], who showed that the neutral complex $\mathrm{VOL}_{2}$ is the major species completely formed in the wide $\mathrm{pH}$ range of 5-9. Based on the above observations, we present here the characterization of the complex formation equilibria of the ligand 4-amino-7-((2-(3-hydroxy-2-methyl-4-oxopyridin-1(4H)-yl)propyl)amino)-4-(3-((2-(3hydroxy-2-methyl-4-oxopyridin-1(4H)-yl)propyl)amino)-3-oxopropyl)-7-oxoheptanoic acid (KC21) (Figure 1) with $\mathrm{V}^{\mathrm{IV}} \mathrm{O}^{2+}$. This ligand contains two 3-hydroxy-4-pyridinones (3,4-HP) units, attached to a backbone unity with the aim of remarkably increasing the thermodynamic and kinetic stability of the vanadium complex, because two chelating groups are needed to complete the $\mathrm{V}^{\mathrm{IV}} \mathrm{O}^{2+}$ coordination sphere. Additionally, as compared with other reported bis(3,4-HP) ligands, the KC21 anchoring unit is an amino-carboxylic group with the capacity to interact with blood proteins, or even to be easily extra-functionalized to provide specific targeting capacity [18]. The synthesis of KC21, its acid base properties and its coordination ability toward Fe(III) and Zn(II) were recently reported [18]. Furthermore, for comparison purposes, we present herein the study of the complex formation equilibria of $\mathrm{V}^{\mathrm{IV}} \mathrm{O}^{2+}$ ion with 1-(3'-aminopropyl)-3-hydroxy-2-methyl-4-pyridinone (L5), the mono-(3,4-HP) attaching arm of KC21 (Figure 1), whose synthesis and characterization were reported by Santos et al. [19].<smiles>Cc1c(O)c(=O)ccn1CCCNC(=O)CCC(N)(CCC(=O)O)CCC(=O)NCCCn1ccc(=O)c(O)c1C</smiles>

Figure 1. Chemical structures of the ligands KC21, L5 and DFP.

\section{Results}

\subsection{Protonation Equilibria}

The protonation equilibria of the L5 ligand were previously studied via potentiometry at a ligand concentration of $2 \times 10^{-3} \mathrm{M}, 0.1 \mathrm{M} \mathrm{KNO}_{3}$ ionic strength and at $25^{\circ} \mathrm{C}$ [19], while in the present work they were studied by combined potentiometric-spectrophotometric titrations. The treatment of experimental data with the HypSpec program [20] led to the protonation constants and to the corresponding speciation plots, reported in Table 1 and Figure 2, respectively. In the following, we briefly discuss the main features of absorptivity spectra (Figure 3A). The completely deprotonated species $\mathrm{L}^{-}$is characterized by two bands, 
at 310 and $228 \mathrm{~nm}$. The first protonation (logK 10.699), related to the $\mathrm{NH}_{2}$ group, leads to a slight decrease in these two bands and to the formation of a new band at $280 \mathrm{~nm}$. These small spectral variations are reasonably connected to a micro speciation equilibrium between the $\mathrm{NH}_{2}$ and the $\mathrm{O}^{-}$groups. The following protonation step $\left(\mathrm{LH}_{2}{ }^{+}\right)$, taking place on the $\mathrm{O}^{-}$group, leads to the disappearance of the band at $310 \mathrm{~nm}$ and to the rise of the band at $280 \mathrm{~nm}$. In the last protonated species $\left(\mathrm{LH}_{3}{ }^{2+}\right)$, the heterocyclic nitrogen atom is mainly protonated [17], the band at $280 \mathrm{~nm}$ strongly decreases with a slight blue shift and a small band forms at $245 \mathrm{~nm}$. The $\log K$ values of the second and third protonation steps (9.494 and 3.142) are, respectively, 0.32 and $0.52 \log K$ units lower than those calculated for the analogous $\log K$ values of DFP by Nurchi et al. [21] (9.494 vs. 9.82 and 3.142 vs. 3.66) (Table 1). These small differences can be associated with the positively charged species, which favor the proton release.

Table 1. Protonation constants of KC21, L5 and DFP ligands evaluated from combined potentiometric$\mathrm{UV}$ spectrophotometric titrations at $25^{\circ} \mathrm{C}, 0.1 \mathrm{M}$ ionic strength. L indicates the completely deprotonated form of ligands. The digits in brackets represent the standard deviation calculated by HypSpec program [20].

\begin{tabular}{|c|c|c|c|c|c|c|c|c|}
\hline \multirow[b]{2}{*}{ Species } & \multicolumn{2}{|c|}{ KC21 [18] } & \multicolumn{4}{|c|}{ L5 } & \multicolumn{2}{|c|}{ DFP [21] } \\
\hline & $\log \beta$ & $\log K$ & Species & $\log \beta$ & $\log K$ & Species & $\log \beta$ & $\log K$ \\
\hline $\mathrm{LH}^{2-}$ & 10.43 & 10.43 & $\mathrm{LH}$ & $10.699(2)$ & 10.699 & LH & 9.82 & 9.82 \\
\hline $\mathrm{LH}_{2}^{-}$ & 20.19 & 9.76 & $\mathrm{LH}_{2}{ }^{+}$ & $20.193(3)$ & 9.494 & $\mathrm{LH}_{2}^{+}$ & 13.48 & 3.66 \\
\hline $\mathrm{LH}_{3}$ & 28.87 & 8.68 & $\mathrm{LH}_{3}{ }^{2+}$ & $23.335(7)$ & 3.142 & & & \\
\hline $\mathrm{LH}_{4}^{+}$ & 33.35 & 4.48 & & & & & & \\
\hline $\mathrm{LH}_{5}{ }^{2+}$ & 36.67 & 3.32 & & & & & & \\
\hline $\mathrm{LH}_{6}{ }^{3+}$ & 39.80 & 3.13 & & & & & & \\
\hline $\begin{array}{c}\text { Ionic } \\
\text { strength }\end{array}$ & \multicolumn{2}{|c|}{$\mathrm{NaCl}$} & \multicolumn{4}{|c|}{$\mathrm{NaCl}$} & \multicolumn{2}{|c|}{$\mathrm{KCl}$} \\
\hline
\end{tabular}

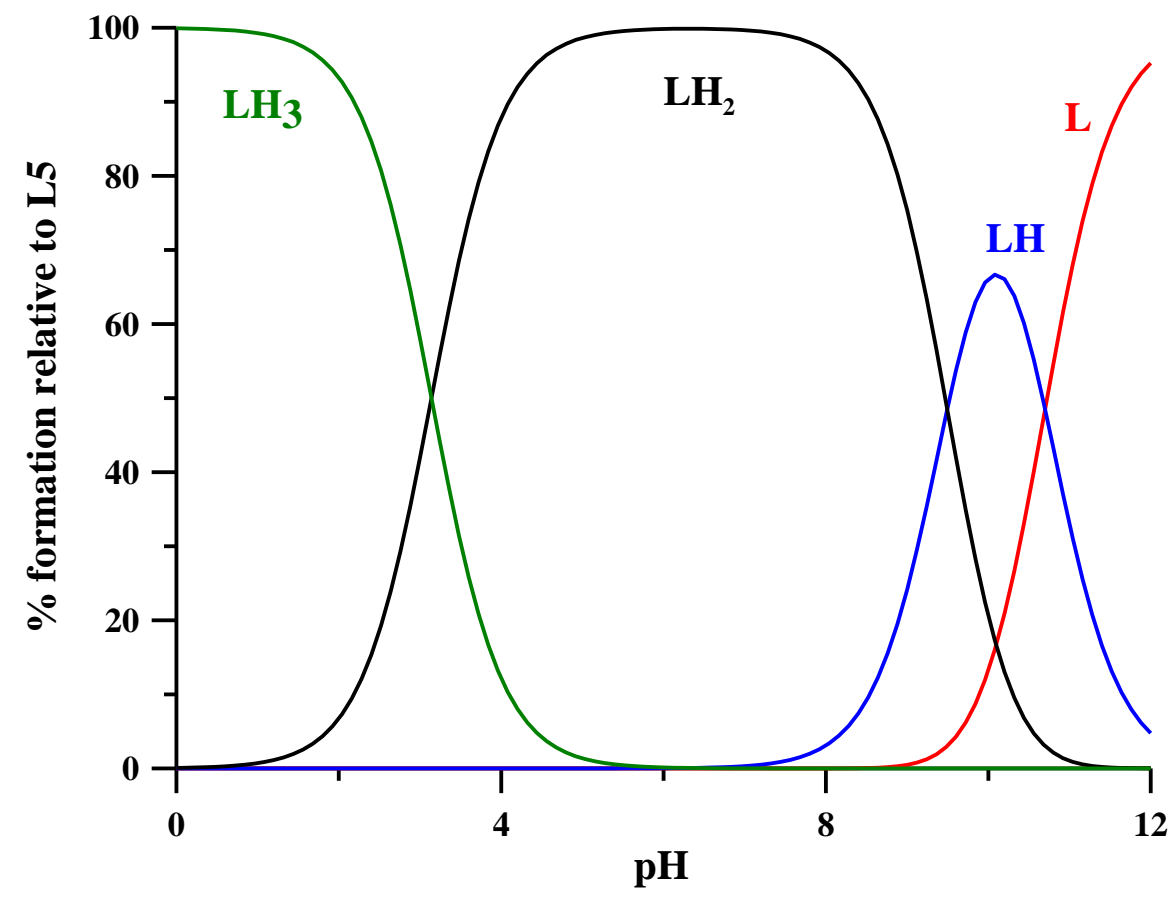

Figure 2. Speciation plot of L5 ligand calculated with HySS [22] according to the protonation constants in Table 1. 

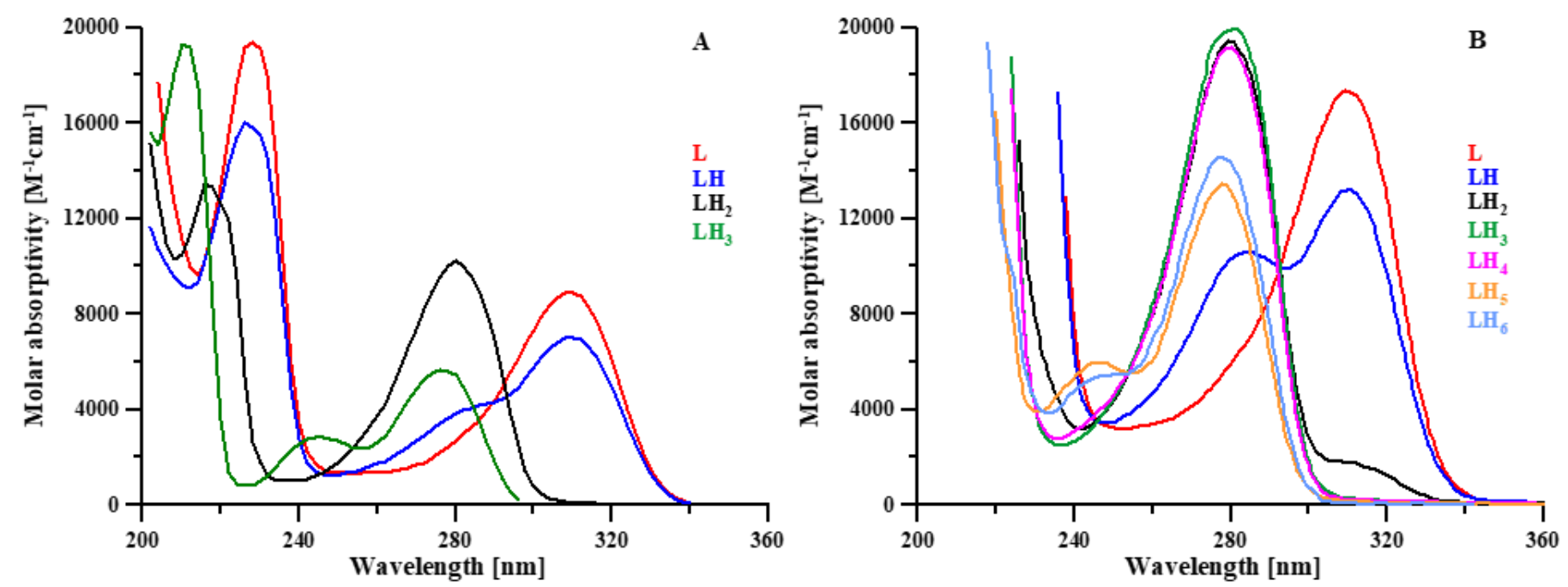

Figure 3. Calculated molar absorptivity spectra of the differently protonated forms of L5 (A) and KC21 (B) ligands.

The protonation equilibria of KC21 (Table 1) were previously discussed in [18] based on potentiometry, $\mathrm{UV},{ }^{1} \mathrm{H}$ and ${ }^{13} \mathrm{C}$ NMR spectroscopy $\left(\log K_{1}=10.43\right.$ and $\log K_{2}=9.76$ for $\mathrm{O}^{-}$groups of the ring; $\log K_{3}=8.68$ for $\mathrm{NH}_{2}$ of the linker; $\log K_{4}=4.48$ and $\log K_{5}=3.32$ for the pyridinone nitrogen atoms; $\log K_{6}=3.13$ for the $\mathrm{COO}^{-}$of the linker). The related absorptivity spectra are reported in Figure 3B.

\subsection{Oxidovanadium(IV) Complex Formation Equilibria}

The equilibria of complex formation of $\mathrm{V}^{\mathrm{IV}} \mathrm{O}^{2+}$ with $\mathrm{L} 5$ and $\mathrm{KC} 21$ ligands were studied using combined potentiometric-spectrophotometric titrations supported by EPR measurements at 1:1 and 1:2 $\mathrm{V}^{\mathrm{IV}} \mathrm{O}^{2+}$ :ligand molar ratios. The complex formation constants are reported in Table 2 and the related speciation plots in Figure 4. The calculated absorptivity spectra of $\mathrm{V}^{\mathrm{IV}} \mathrm{O}^{2+}$-L5 depicted in Figure $5 \mathrm{~A}$ give evidence for the formation of the 1:1 species $\left[\left(\mathrm{V}^{\mathrm{IV}} \mathrm{O}\right) \mathrm{LH}\right]^{2+}$, where $\mathrm{V}^{\mathrm{IV}} \mathrm{O}^{2+}$ is coordinated by one $\mathrm{L} 5$ unit, and of the major $1: 2$ species $\left[\left(\mathrm{V}^{\mathrm{IV}} \mathrm{O}\right) \mathrm{L}_{2} \mathrm{H}_{2}\right]^{2+}$, in which a second $\mathrm{L} 5$ unit enters in the coordination. The speciation model (Figure 4$)$ strictly resembles that reported for $\mathrm{DFP}\left(\left[\left(\mathrm{V}^{\mathrm{IV}} \mathrm{O}\right) \mathrm{L}\right]^{+}\right.$with $\log K=12.18$, $\left[\left(\mathrm{V}^{\mathrm{IV}}\right) \mathrm{OL}_{2}\right]$ with $\log \mathrm{K}=22.83,\left[\left(\mathrm{~V}^{\mathrm{IV}} \mathrm{O}\right) \mathrm{L}_{2} \mathrm{H}_{-1}\right]^{-}$with $\log \mathrm{K}=12.43$ and $\left[\left(\mathrm{V}^{\mathrm{IV}} \mathrm{O}\right)_{2} \mathrm{~L}_{3} \mathrm{H}_{2}\right]^{+}$with $\log K=38.5)[17]$. The species $\left[\left(\mathrm{V}^{\mathrm{IV}} \mathrm{O}\right) \mathrm{L}\right]^{2+}$ is now replaced by $\left[\left(\mathrm{V}^{\mathrm{IV}} \mathrm{O}\right) \mathrm{LH}\right]^{2+}$ and $\left[\left(\mathrm{V}^{\mathrm{IV}} \mathrm{O}\right) \mathrm{L}_{2}\right]$ by $\left[\left(\mathrm{V}^{\mathrm{IV}} \mathrm{O}\right) \mathrm{L}_{2} \mathrm{H}_{2}\right]^{2+}$. As mentioned in the discussion of the protonation equilibria, this behavior can be attributed to the presence of positively charged species that is also reflected in the $\mathrm{pM}$ differences (11.7 for L5 vs. 13.9 for DFP).

Table 2. Complex formation constants and $\mathrm{pM}$ values of $\mathrm{V}^{\mathrm{IV}} \mathrm{O}^{2+}$ with $\mathrm{KC} 21$, $\mathrm{L} 5$ and DFP ligands evaluated from combined potentiometric-UV titrations at $25^{\circ} \mathrm{C}, 0.1 \mathrm{M} \mathrm{NaCl}$ ionic strength using HypSpec program [20]. pM $=-\log _{10}\left[\mathrm{M}_{\text {free }}\right]$ with $[\mathrm{M}]=10^{-6} \mathrm{M}$, [ligand $]=10^{-5} \mathrm{M}$ and $\mathrm{pH}=7.4$.

\begin{tabular}{|c|c|c|c|c|c|}
\hline \multicolumn{2}{|c|}{ КС21 } & \multicolumn{2}{|c|}{ L5 } & \multicolumn{2}{|l|}{ DFP [17] } \\
\hline Species & $\log \beta$ & Species & $\log \beta$ & Species & $\log \beta$ \\
\hline$\left[\left(\mathrm{V}^{\mathrm{IV}} \mathrm{O}\right) \mathrm{LH}_{4}\right]^{3+}$ & $40.74(1)$ & {$\left[\left(\mathrm{V}^{\mathrm{IV}} \mathrm{O}\right) \mathrm{LH}\right]^{2+}$} & $21.398(4)$ & {$\left[\left(\mathrm{V}^{\mathrm{IV}} \mathrm{O}\right) \mathrm{L}\right]^{+}$} & 12.18 \\
\hline$\left[\left(\mathrm{V}^{\mathrm{VV}} \mathrm{O}\right) \mathrm{LH}_{2}\right]^{+}$ & $36.31(1)$ & {$\left[\left(\mathrm{V}^{\mathrm{IV}} \mathrm{O}\right) \mathrm{L}_{2} \mathrm{H}_{2}\right]^{2+}$} & $41.48(1)$ & {$\left[\left(\mathrm{V}^{\mathrm{IV}} \mathrm{O}\right) \mathrm{L}_{2}\right]$} & 22.83 \\
\hline$\left[\left(\mathrm{V}^{\mathrm{IV}} \mathrm{O}\right) \mathrm{LH}\right]$ & $33.47(1)$ & & & {$\left[\left(\mathrm{V}^{\mathrm{IV}} \mathrm{O}\right) \mathrm{L}_{2} \mathrm{H}_{-1}\right]^{-}$} & 12.24 \\
\hline$\left[\left(\mathrm{V}^{\mathrm{IV}} \mathrm{O}\right) \mathrm{L}\right]^{-}$ & $27.55(1)$ & & & {$\left[\left(\mathrm{V}^{\mathrm{IV}} \mathrm{O}\right) \mathrm{L}_{3} \mathrm{H}_{2}\right]^{+}$} & 38.5 \\
\hline$\left[\left(\mathrm{V}^{\mathrm{IV}} \mathrm{O}\right) \mathrm{LH}_{-1}\right]^{2-}$ & $17.42(4)$ & & & $\left.\left[\left(\mathrm{V}^{\mathrm{IV}}\right)_{2}\right)_{2} \mathrm{~L}_{2} \mathrm{H}_{-2}\right]^{2-}$ & 16.43 \\
\hline $\mathrm{p}\left(\mathrm{V}^{\mathrm{IV}} \mathrm{O}^{2+}\right)$ & 21.8 & & 11.7 & & 13.91 \\
\hline
\end{tabular}



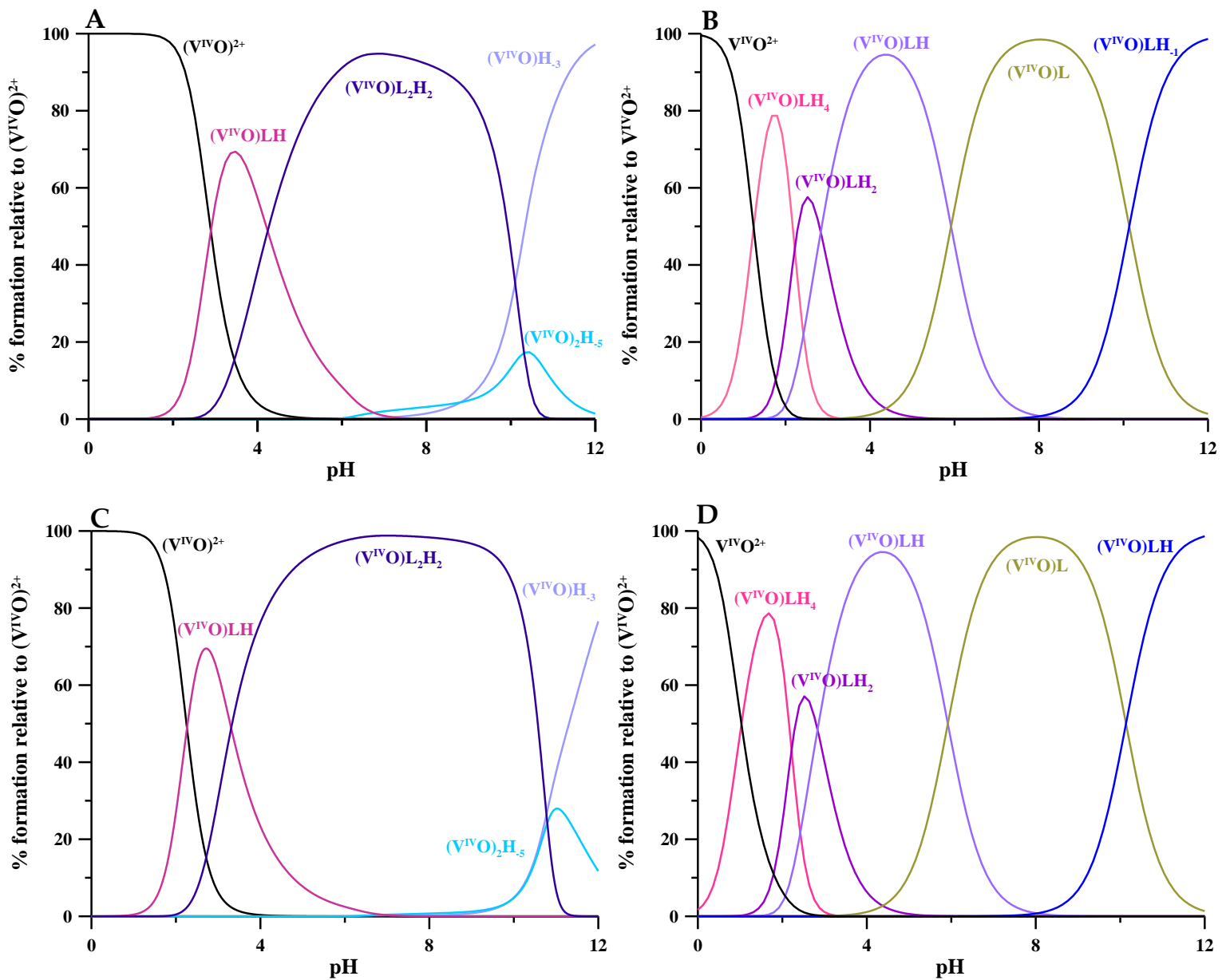

Figure 4. Speciation plots of $\mathrm{V}^{\mathrm{IV}} \mathrm{O}^{2+}$-ligand systems calculated with HySS program [22]. Top: UVspectrophotometric titration conditions, $1: 2 \mathrm{~V}^{\mathrm{IV}} \mathrm{O}^{2+}$ :ligand molar ratio and ligand concentration $3 \times 10^{-4} \mathrm{M}$ and $5 \times 10^{-4} \mathrm{M}$, respectively, for L5 and KC21, (A) L5, (B) KC21. Bottom: EPR measurements conditions, $1: 2$ and $1: 1 \mathrm{~V}^{\mathrm{IV}} \mathrm{O}^{2+}$ :ligand molar ratio, respectively, for $\mathrm{L} 5$ and $\mathrm{KC} 21$ at $\mathrm{V}^{\mathrm{IV}} \mathrm{O}^{2+}$ concentration $2 \times 10^{-3} \mathrm{M}$, (C) L5, (D) KC21. Charges are omitted for simplicity.
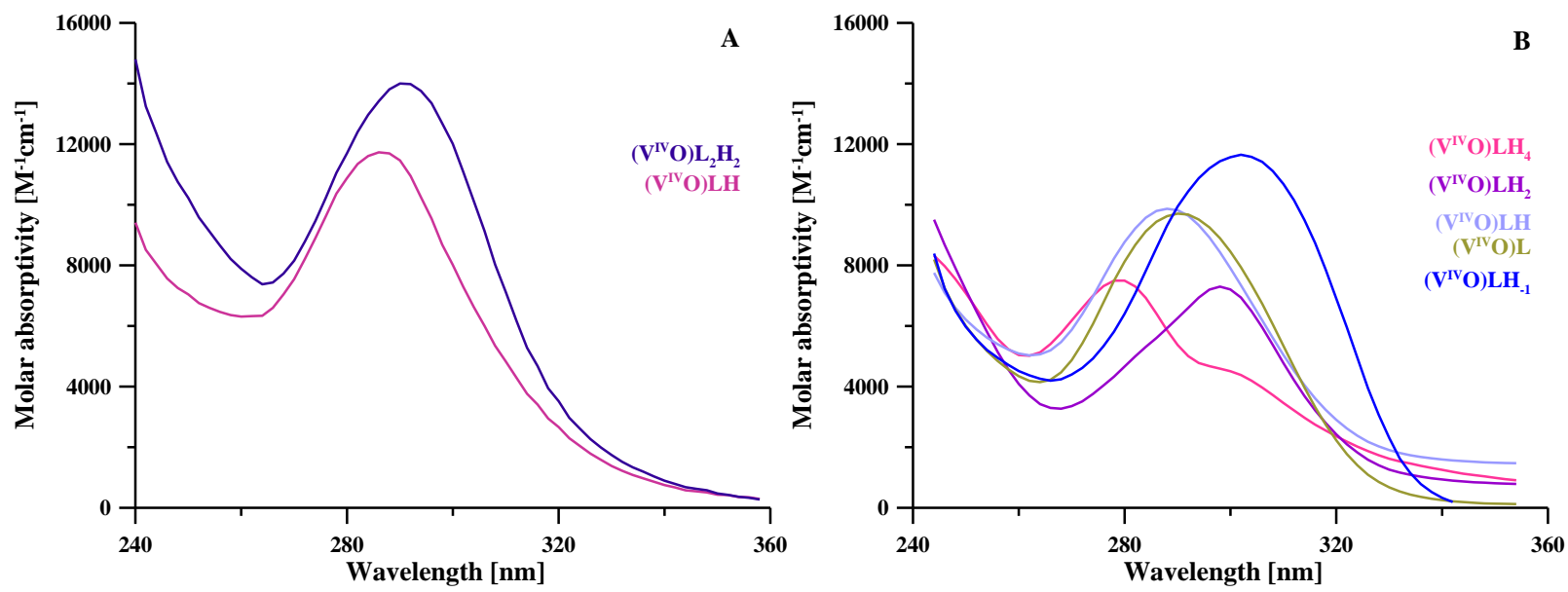

Figure 5. Calculated molar absorptivity spectra of differently protonated forms of $\mathrm{V}^{\mathrm{IV}} \mathrm{O}^{2+}$ complexes with L5 (A) and KC21 (B) ligands.

Concerning the $\mathrm{V}^{\mathrm{IV}} \mathrm{O}^{2+}-\mathrm{KC} 21$ complexes, during the spectrophotometric titration at $1: 1 \mathrm{~V}^{\mathrm{IV}} \mathrm{O}^{2+}$ :ligand molar ratio, some turbidity was observed above $\mathrm{pH} 3$, giving dirty spectra. 
Therefore, only the data collected at $1: 2 \mathrm{~V}^{\mathrm{IV}} \mathrm{O}^{2+}$ :ligand molar ratio were used in the HypSpec treatment. The UV-spectrophotometric data (Figure 5B) show the formation of differently protonated 1:1 complexes whose complex formation constants and speciation plot are reported in Table 2 and Figure 4. The formation of the $\left[\left(\mathrm{V}^{\mathrm{IV}} \mathrm{O}\right) \mathrm{LH}_{4}\right]^{3+}$ complex starts at extremely acidic conditions ( $\mathrm{pH} 0$ ), reaching a maximum at $\mathrm{pH} 1.7$; in this complex, $\mathrm{V}^{\mathrm{IV}} \mathrm{O}^{2+}$ is presumably coordinated by two oxygen atoms of one 3,4-HP moiety, predominantly by the second until it is protonated on $\mathrm{O}^{-}$and $\mathrm{N}$ atoms, as well as on the $\mathrm{NH}_{2}$ and $\mathrm{COO}^{-}$. This is substantiated by the decrease in the band at $280 \mathrm{~nm}$ related to the protonated $\mathrm{O}^{-}$ in the 3,4-HP moiety. After $\mathrm{pH} 2$, the formation of $\left[\left(\mathrm{V}^{\mathrm{IV}} \mathrm{O}\right) \mathrm{LH}_{2}\right]^{+}$takes place, reaching its maximum at $\mathrm{pH} 2.5$, where $\mathrm{V}^{\mathrm{IV}} \mathrm{O}^{2+}$ is coordinated by both the 3,4-HP moieties, while the ligand is still protonated on the $\mathrm{NH}_{2}$ and $\mathrm{COO}^{-}$. The loss of a proton comes at about 0.3 units lower ( $\mathrm{pK} 2.84$ ) than that in the free ligand. A further proton is lost at $\mathrm{pK} 5.92$, presumably from the charged $\mathrm{NH}_{3}{ }^{+}$, since it does not give significant spectral variation, as would be expected for the deprotonation of an amino group. The last deprotonation (pK 10.13) concerns the coordinated water to give $\left[\left(\mathrm{V}^{\mathrm{IV}} \mathrm{O}\right) \mathrm{LH}_{-1}\right]^{2-}$.

\section{3. $E P R$}

The EPR spectra of the $\mathrm{V}^{\mathrm{IV}} \mathrm{O}^{2+}$-L5 system collected at the $1: 2 \mathrm{~V}^{\mathrm{IV}} \mathrm{O}^{2+}$ :ligand molar ratio at increasing $\mathrm{pH}$ (Figure 6A) show the formation of 1:2 complexes.

A

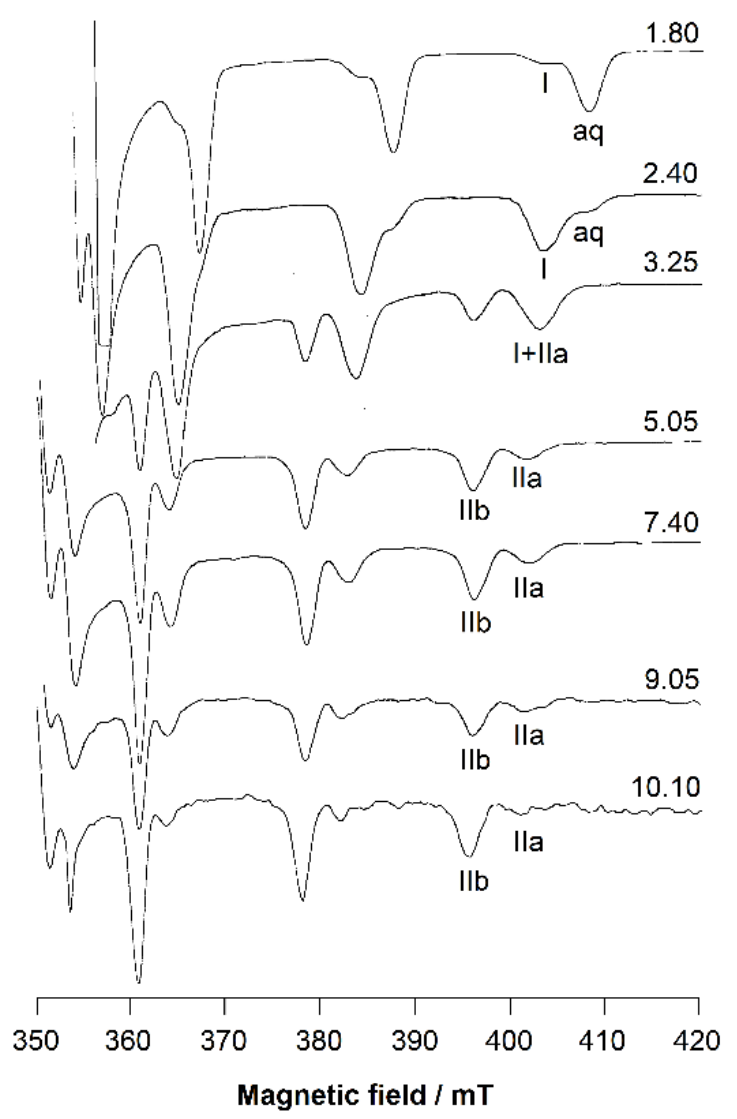

B

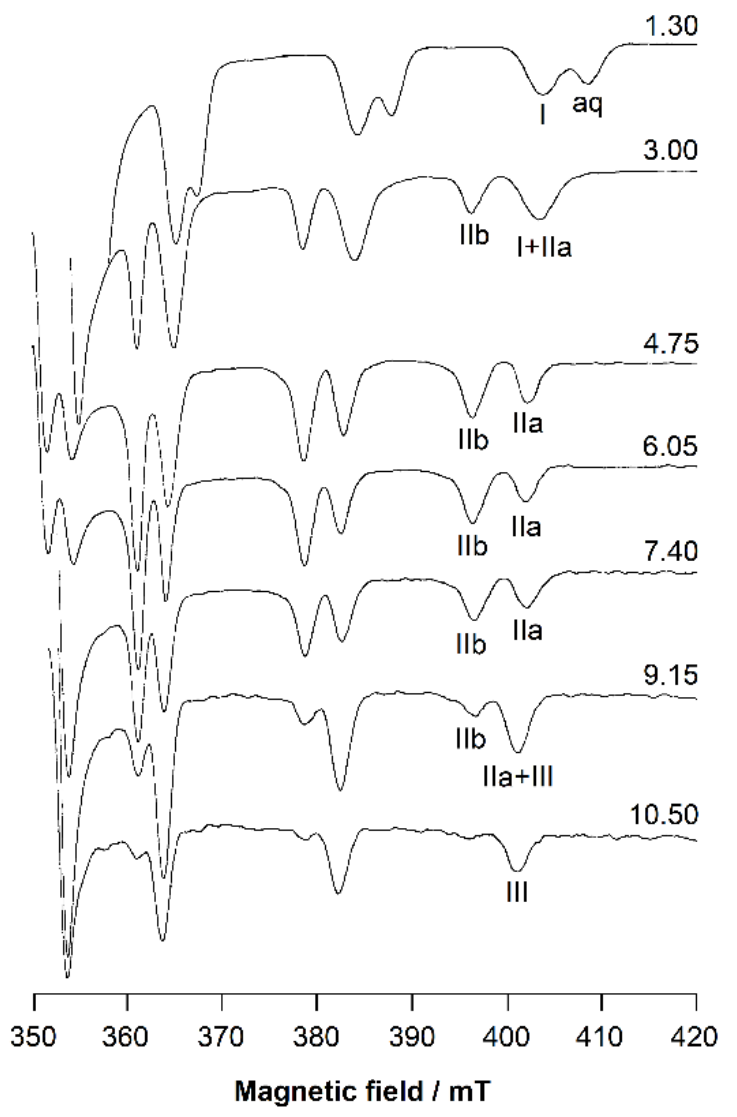

Figure 6. High field region of the anisotropic X-band EPR spectra, at increasing $\mathrm{pH}$, of $\mathrm{V}^{\mathrm{IV}} \mathrm{O}^{2+}-\mathrm{L} 5$ system at $1: 2 \mathrm{~V}^{\mathrm{IV}} \mathrm{O}^{2+}$ :ligand molar ratio $(\mathbf{A})$ and $\mathrm{V}^{\mathrm{IV}} \mathrm{O}^{2+}-\mathrm{KC} 21$ system at $1: 1 \mathrm{~V}^{\mathrm{IV}} \mathrm{O}^{2+}$ :ligand molar ratio $(\mathbf{B}) . \mathrm{V}^{\mathrm{IV}} \mathrm{O}^{2+}$ concentration is $2 \times 10^{-3} \mathrm{M}$.

The $\left[\left(\mathrm{V}^{\mathrm{IV}} \mathrm{O}\right) \mathrm{LH}\right]^{2+}$ species is observed in the $\mathrm{pH}$ range of $2-3$. Its spin Hamiltonian parameters are $g_{z}=1.938$ and $A_{z}=171.0 \times 10^{-4} \mathrm{~cm}^{-1}$ (the $M_{\mathrm{I}}=7 / 2$ resonance of this species is denoted with $\mathrm{I})$. From $\mathrm{pH} 3$, the formation of the major species $\left[\left(\mathrm{V}^{\mathrm{IV}} \mathrm{O}\right) \mathrm{L}_{2} \mathrm{H}_{2}\right]^{2+}$ is 
observed up to $\mathrm{pH} 10.5$, with the amine group still protonated. In the range of existence of $\left[\left(\mathrm{V}^{\mathrm{IV}} \mathrm{O}\right) \mathrm{L}_{2} \mathrm{H}_{2}\right]^{2+}$, the EPR spectra show two sets of resonances (IIa and IIb), suggesting the presence of two species. The ratio between the intensity of the spectral signals, which remains constant along the $\mathrm{pH}$ range 5-10, indicates that the two complexes are in equilibrium. The spin Hamiltonian parameters are $g_{z}=1.940$ and $A_{z}=166.6 \times 10^{-4} \mathrm{~cm}^{-1}$ for IIa, and $g_{z}$ $=1.950$ and $A_{z}=159.4 \times 10^{-4} \mathrm{~cm}^{-1}$ for IIb. Based on an "additivity relationship" [23,24], these values are compatible with a cis-octahedral $\mathrm{V}^{\mathrm{IV}} \mathrm{O}^{2+}$ complex with an (equatorialequatorial) and an (equatorial-axial) arrangement of the two L5 units with respect to the $\mathrm{V}=\mathrm{O}$ bond, and a water molecule that completes the equatorial coordination sphere (IIa) and a square pyramidal species with $2 \times$ (equatorial-equatorial) arrangements (IIb). The $A_{z}$ values, slightly lower than that expected from the "additivity relationship", can be explained assuming that hydroxypyridinones have an electronic structure intermediate between the hydroxypyrones and catechols, with a partial positive charge on the $\mathrm{N}$ atom in position 1 of the ring and a pseudo-aromatic electronic structure that approaches that of 1,2-dihydroxybenzene [25]. This behavior is similar to DFP [17] and other pyridinones derivatives [26] and confirms that the terminal amino donor does not take part in the metal coordination. At $\mathrm{pH}>10$, the EPR intensity significantly decreases due to the hydrolytic processes and formation of the hydroxide species $\left[\left(\mathrm{V}^{\mathrm{IV}} \mathrm{O}\right)_{2}(\mathrm{OH})_{5}\right]^{-}$, EPR-silent.

The EPR spectra of KC21 presented in Figure 6B suggest that the complexation starts around $\mathrm{pH} 1$ with the formation of the species $\left[\left(\mathrm{V}^{\mathrm{IV}} \mathrm{O}\right) \mathrm{LH}_{4}\right]^{3+}$ (whose $M_{\mathrm{I}}=7 / 2$ resonance is indicated with $\mathrm{I})$, where only one $\left(\mathrm{CO}, \mathrm{O}^{-}\right)$group binding the $\mathrm{V}^{\mathrm{IV}} \mathrm{O}^{2+}$ ion, presumably $\left[\left(\mathrm{V}^{\mathrm{IV}} \mathrm{O}\right) \mathrm{LH}_{4}\right]^{3+}$, with the amino and pyridine nitrogen, the second $-\mathrm{OH}$ and $\mathrm{COOH}$ still protonated. The coordination mode remains the same, $\left(\mathrm{CO}, \mathrm{O}^{-}\right)$, in the transient species $\left[\left(\mathrm{V}^{\mathrm{IV}} \mathrm{O}\right) \mathrm{LH}_{2}\right]^{+}$. With the following two deprotonations, $\left[\left(\mathrm{V}^{\mathrm{IV}} \mathrm{O}\right) \mathrm{LH}\right]$ and $\left[\left(\mathrm{V}^{\mathrm{IV}} \mathrm{O}\right) \mathrm{L}\right]^{-}$, both the $\left(\mathrm{CO}, \mathrm{O}^{-}\right)$groups can interact with $\mathrm{V}^{\mathrm{IV}} \mathrm{O}^{2+}$ ion. In this case, also, two sets of resonances are detected (IIa and IIb), indicating the presence of two species in equilibrium, the cisoctahedral and the square pyramidal complexes, shown in Figure 7. The EPR parameters are similar to those measured for L5 (Table 3). Notably, the relative amount of IIa compared to IIb is larger than that with L5. This observation can be explained bythe high steric constraints associated with the binding of the two $\left(\mathrm{CO}, \mathrm{O}^{-}\right)$groups of $\mathrm{KC} 21$ on the equatorial plane; instead, in the cis-octahedral complex the arrangement (eq-eq; eq-ax) results in a more relaxed structure. After $\mathrm{pH}$ 9, the species III is detected. Its spin Hamiltonian parameters are $g_{z}=1.943$ and $A_{z}=162.2 \times 10^{-4} \mathrm{~cm}^{-1}$ and can be ascribed to a hydroxide complex upon the deprotonation of the water ligand, $\left[\left(\mathrm{V}^{\mathrm{IV}} \mathrm{O}\right) \mathrm{LH}_{-1}\right]^{2-}$, in agreement with thermodynamic results. In such a complex, the two $\left(\mathrm{CO}, \mathrm{O}^{-}\right)$functions should be arranged in an (eq-eq) and (eq-ax) mode, and an $\mathrm{OH}^{-}$ion should occupy the fourth equatorial site. As observed in the literature $[17,26]$, the formation of this complex shifts to the right the equilibrium square pyramidal $\rightleftarrows$ cis-octahedral species. The $\mathrm{pK}$ for the deprotonation of $\mathrm{H}_{2} \mathrm{O}$ ligand, in the $\mathrm{pH}$ range 9-10, is comparable to those reported for other pyridinones. Moreover, the decrease in $A_{z}\left(\sim 4 \times 10^{-4} \mathrm{~cm}^{-1}\right)$ is compatible with the transformation of a water into a hydroxide ligand.

Table 3. EPR spin Hamiltonian parameters for $\mathrm{V}^{\mathrm{IV}} \mathrm{O}^{2+}$ complexes formed in aqueous solution by L5 and KC21.

\begin{tabular}{|c|c|c|c|c|c|}
\hline Ligand & Complex & Symbol in Figure 6 & $g_{z}$ & $A_{z}{ }^{a}$ & Arrangement of the Ligand Donors \\
\hline \multirow[t]{3}{*}{ L5 } & $\left(\mathrm{V}^{\mathrm{IV}} \mathrm{O}\right) \mathrm{LH}$ & I & 1.938 & 171.0 & eq-eq \\
\hline & cis- $\left(\mathrm{V}^{\mathrm{IV}} \mathrm{O}\right) \mathrm{L}_{2} \mathrm{H}_{2}$ & IIa & 1.940 & 166.6 & eq-eq; eq-ax \\
\hline & $\left(\mathrm{V}^{\mathrm{IV}} \mathrm{O}\right) \mathrm{L}_{2} \mathrm{H}_{2}$ & IIb & 1.950 & 159.4 & eq-eq; eq-eq \\
\hline \multirow[t]{4}{*}{ KC21 } & $\left(\mathrm{V}^{\mathrm{IV}} \mathrm{O}\right) \mathrm{LH}_{4} /\left(\mathrm{V}^{\mathrm{IV}} \mathrm{O}\right) \mathrm{LH}_{2}$ & $\mathbf{I}$ & 1.938 & 170.8 & eq-eq \\
\hline & cis- $\left(\mathrm{V}^{\mathrm{IV}} \mathrm{O}\right) \mathrm{LH} /\left(\mathrm{V}^{\mathrm{IV}} \mathrm{O}\right) \mathrm{L}$ & IIa & 1.940 & 166.8 & eq-eq; eq-ax \\
\hline & $\left(\mathrm{V}^{\mathrm{IV}} \mathrm{O}\right) \mathrm{LH} /\left(\mathrm{V}^{\mathrm{IV}} \mathrm{O}\right) \mathrm{L}$ & IIb & 1.951 & 159.1 & eq-eq; eq-eq \\
\hline & $\left(\mathrm{V}^{\mathrm{IV}} \mathrm{O}\right) \mathrm{LH}_{-1}$ & III & 1.943 & 162.2 & eq-eq; eq-ax \\
\hline
\end{tabular}

$$
{ }^{\mathrm{a}} A_{z} \text { in } 10^{-4} \mathrm{~cm}^{-1} \text {. }
$$



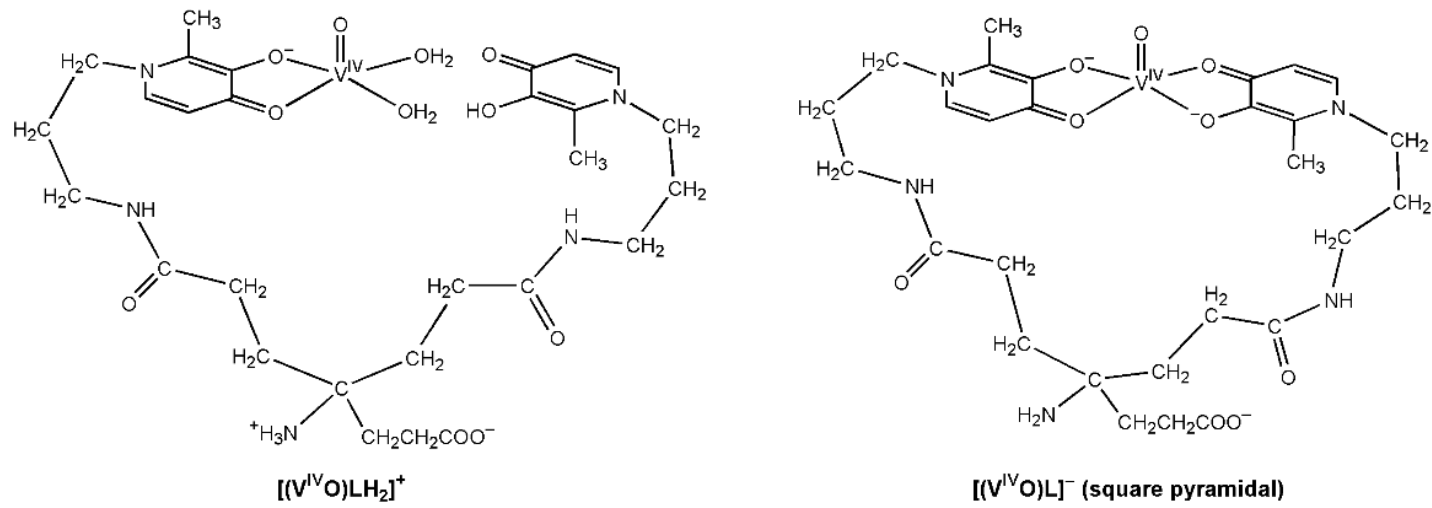

$\left[\left(\mathrm{V}^{\mathrm{IV} O}\right)_{\mathrm{L}}\right]^{-}$(square pyramidal)

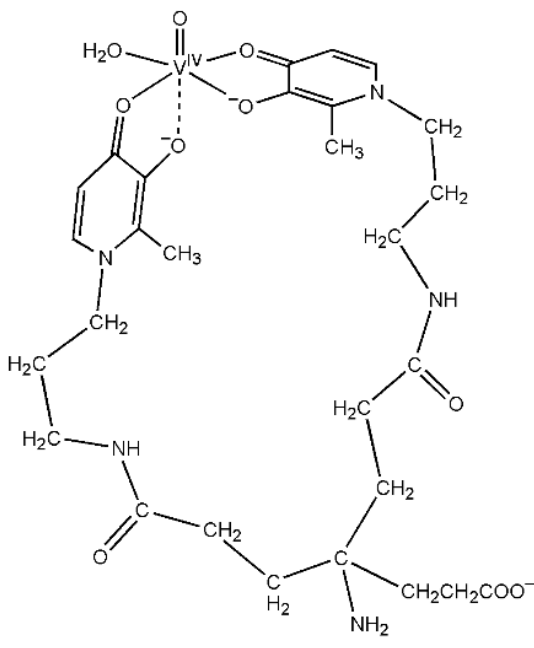

$\left[\left(V^{I V} O\right)\right]^{-}$(cis-octahedral)

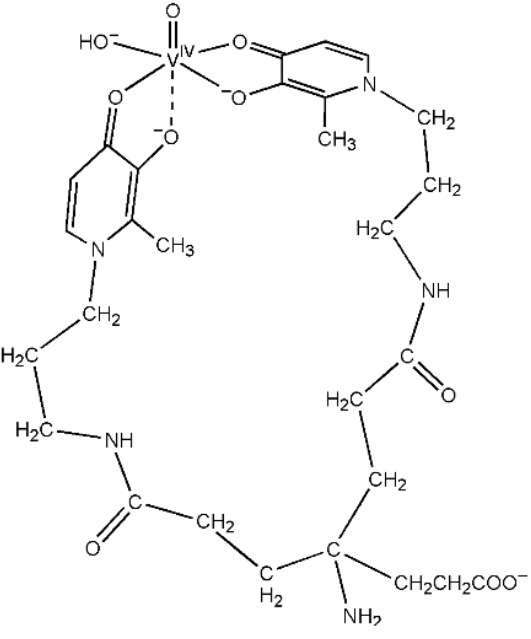

$\left[\left(\mathrm{V}^{\mathrm{IV} O}\right) \mathrm{LH}_{-1}\right]^{2-}$

Figure 7. Molecular drawings of the $\mathrm{V}^{\mathrm{IV}} \mathrm{O}^{2+}$ species with the ligand $\mathrm{KC} 21$ based on the solution studies.

\section{Materials and Methods}

\subsection{Reagents}

$\mathrm{NaOH}, \mathrm{NaCl}, \mathrm{HCl}$ and $\mathrm{VOSO}_{4} \cdot 3 \mathrm{H}_{2} \mathrm{O}$ were Sigma Aldrich products, and all the reagents were used without any further purification. The L5 and KC21 ligands were synthetized as previously reported [18,19]. Oxidovanadium(IV) sulfate solution $\sim 0.1 \mathrm{M}$ was prepared weekly, acidified with a stoichiometric amount of $\mathrm{HCl}$ to prevent hydrolysis and standardized by redox titration $[27,28]$. All solutions were prepared using grade A glassware and ultrapure water (conductivity $<0.1 \mu \mathrm{S}$ ).

\subsection{Solution Equilibria Studies}

The complex formation equilibria were studied at $25^{\circ} \mathrm{C}$ and $0.1 \mathrm{M} \mathrm{NaCl}$ ionic strength through combined potentiometric-spectrophotometric titrations at $1: 1$ and $1: 2 \mathrm{~V}^{\mathrm{IV}} \mathrm{O}^{2+}$ :ligand molar ratios and a constant ligand concentration $3.0 \times 10^{-4} \mathrm{M}$ for L5 and $5.0 \times 10^{-4} \mathrm{M}$ for KC21. Potentiometric measurements were performed with a dEcotrode plus Metrohm combined glass electrode connected to 888 Titrando (Metrohm AG, Herisau, Switzerland). The electrode was calibrated daily for hydrogen ion concentration via $\mathrm{HCl}$ standard titration with $\mathrm{NaOH}$ in the used experimental conditions, and data were analyzed using Gran's method [29]. Spectrophotometric measurements were performed in the 200-400 nm wavelength range with a $0.2 \mathrm{~cm}$ fiber optic dip probe connected to an Agilent Cary $60 \mathrm{UV}$ vis spectrophotometer. Potentiometric and spectrophotometric data were processed using the HyperQuad and HypSpec programs, respectively [20,30]. Log $\beta_{\text {pqr }}$ values refer to the overall equilibria $p \mathrm{M}+q \mathrm{H}+r \mathrm{~L} \rightleftarrows \mathrm{M}_{\mathrm{p}} \mathrm{H}_{\mathrm{q}} \mathrm{L}_{\mathrm{r}}$ (electrical charges omitted). The fol- 
lowing hydrolysis constants of $\mathrm{V}^{\mathrm{IV}} \mathrm{O}^{2+}$ were assumed for the calculations: $\left[\mathrm{V}^{\mathrm{IV}} \mathrm{O}(\mathrm{OH})\right]^{+}$ $\left(\log \beta_{1-1}=-5.94\right),\left[\left(\mathrm{V}^{\mathrm{IV}} \mathrm{O}\right)_{2}(\mathrm{OH})_{2}\right]^{2+}\left(\log \beta_{2-2}=-6.95\right),[31]\left[\mathrm{V}^{\mathrm{IV}} \mathrm{O}(\mathrm{OH})_{3}\right]-\left(\log \beta_{1-3}=-18.0\right)$ and $\left[\left(\mathrm{V}^{\mathrm{IV}} \mathrm{O}\right)_{2}(\mathrm{OH})_{5}\right]^{-}\left(\log \beta_{2-5}=-22.0\right)[32,33]$.

\subsection{EPR Experiments}

The solutions were prepared by dissolving in ultrapure water (from a millipore Milli$\mathrm{Q}$ Academic purification system) a weighed amount of $\mathrm{VOSO}_{4} \cdot 3 \mathrm{H}_{2} \mathrm{O}$ and $\mathrm{L} 5$ or $\mathrm{KC} 21$ for a metal ion concentration of $2 \mathrm{mM}$ and 1:1 and 1:2 $\mathrm{V}^{\mathrm{IV}} \mathrm{O}^{2+}$ :ligand molar ratios. The solutions were bubbled with argon in order to avoid the oxidation of the metal ion. The $\mathrm{pH}$ values were varied with diluted solution of $\mathrm{H}_{2} \mathrm{SO}_{4}$ and $\mathrm{NaOH}$. DMSO was added to each sample to uniformly freeze the solutions and prevent a concentration gradient during freezing. Anisotropic EPR spectra were recorded at $120 \mathrm{~K}$ with an X-band Varian E-9 spectrometer equipped with a variable temperature unit. The microwave frequency was $9.15-9.16 \mathrm{GHz}$, microwave power $20 \mathrm{~mW}$, time constant $0.5 \mathrm{~s}$, modulation frequency $100 \mathrm{kHz}$ and modulation amplitude $0.4 \mathrm{mT}$.

\section{Conclusions}

The use of the tetradentate ligand KC21, in which two deferiprone units are connected through a long and flexible linker, has led to the formation of an extremely stable 1:1 complex with a $\mathrm{V}^{\mathrm{IV}} \mathrm{O}^{2+}$ ion. This formation of the neutral form $\left(\mathrm{V}^{\mathrm{IV}} \mathrm{O}\right) \mathrm{LH}$ that reaches its maximum near $\mathrm{pH} 4.5$, the negatively charged form $\left[\left(\mathrm{V}^{\mathrm{IV}} \mathrm{O}\right) \mathrm{L}\right]^{-}$that is stable in the $\mathrm{pH}$ range 6-10, and then of the hydroxo complex $\left[\left(\mathrm{V}^{\mathrm{IV}} \mathrm{O}\right) \mathrm{LH}_{-1}\right]^{2-}$ is observed. The EPR spectra related to these complexes shows two sets of resonances indicative of the presence of two species in equilibrium, the cis-octahedral and the square pyramidal complexes. Remembering that $\mathrm{pM}$ gives the real evaluation of the ligand strength in its interaction with a given metal ion, and the extremely high $\mathrm{pV}^{\mathrm{IV}} \mathrm{O}^{2+}$ value for a $\mathrm{KC} 21$ ligand 21.8 has to be pointed out. This value is about 8 units greater than the corresponding value of 13.9 found for the parent molecule deferiprone. A similar increase in the $\mathrm{pM}$ passing from DFP to $\mathrm{KC} 21$ was found for $\mathrm{Fe}^{\mathrm{III}}, \mathrm{Al}^{\mathrm{III}}$ and $\mathrm{Zn}^{\mathrm{II}}$ (5.1, 3.2 and 2.1, respectively) [18]. This increase in stability can be accounted for an entropic stabilization of the complexes formed by a ligand bearing two different DFP units. In simplistic terms, the value of this increment is indicative of a favorable conformation of the ligand in the coordination of a given metal ion, and in this respect, the extraordinary efficiency of $\mathrm{KC} 21$ in $\mathrm{V}^{\mathrm{IV}} \mathrm{O}^{2+}$ coordination has to be remarked. The good stability of $\left[\left(\mathrm{V}^{\mathrm{IV}} \mathrm{O}\right) \mathrm{L}\right]^{-}$could positively influence its absorption and transport, minimizing the hydrolytic processes and precipitation of the hydroxide $\mathrm{V}^{\mathrm{IV}} \mathrm{O}(\mathrm{OH})_{2}$ at the low vanadium concentration present in the biological fluids of humans treated with vanadium compounds $(1-10 \mu \mathrm{M})$ [34-38]. The presence of the $\mathrm{COOH}$ and $\mathrm{NH}_{2}$ groups on the KC21 skeleton constitutes an essential feature of this ligand, since these groups can interact with blood proteins and facilitate the complex blood transport or cell uptake. On the other hand, its possible extra-functionalization can provide specific capacity for further biotargeting or grafting of this ligand/complex on solid nanomaterials, expanding the potential clinical applications of this chelating agent and its complexes. Overall, the present results show a new chemical platform for potent vanadium complex and encourage the progression of these studies with biochemical and biological assays. We envisage prospective medical applications as insulinomimetics or even as anticancer agents.

Author Contributions: Conceptualization, V.M.N., E.G. and M.A.S.; methodology, G.C. and R.C.; software, G.C. and R.C.; validation, G.C. and E.G.; formal analysis, V.M.N., R.C. and M.A.S.; investigation, R.C., A.F. and E.G.; resources, V.M.N., E.G. and M.A.S.; data curation, V.M.N., R.C., G.C., A.F. and E.G.; writing-original draft preparation, V.M.N. and E.G.; writing—review and editing, V.M.N., R.C., E.G. and M.A.S.; visualization, V.M.N., G.C., R.C., M.A.S. and E.G.; supervision V.M.N.; project administration, V.M.N.; funding acquisition, V.M.N., E.G. and M.A.S. All authors have read and agreed to the published version of the manuscript. 
Funding: This research was funded by RAS, Regione Autonoma Sardegna, grant number RASSR79857; University of Cagliari and Fondazione di Sardegna, grant number CUP F72F20000240007 (2019); Fundação para a Ciência e Tecnologia (FCT), projects UIDB/00100/2020, UIDP/00100/2020 and LA/P/0056/2020; COST Action CA18202, NECTAR, supported by COST (European Cooperation in Science and Technology).

Institutional Review Board Statement: Not applicable.

Informed Consent Statement: Not applicable.

Data Availability Statement: The data are available from the authors.

Conflicts of Interest: The authors declare no conflict of interest.

\section{References}

1. Costa Pessoa, J.; Etcheverry, S.; Gambino, D. Vanadium compounds in medicine. Coord. Chem. Rev. 2015, 301-302, 24-48. [CrossRef] [PubMed]

2. Rehder, D. Perspectives for vanadium in health issues. Future Med. Chem. 2016, 8, 325-338. [CrossRef] [PubMed]

3. Crans, D.C.; Yang, L.; Haase, A.; Yang, X. Health Benefits of Vanadium and Its Potential as an Anticancer Agent. In Metallo-Drugs: Development and Action of Anticancer Agents; Sigel, A., Sigel, H., Freisinger, E., Sigel, R.K.O., Eds.; De Gruyter GmbH: Berlin, Germany, 2018; pp. 251-280.

4. Treviño, S.; Díaz, A.; Sánchez-Lara, E.; Sanchez-Gaytan, B.L.; Perez-Aguilar, J.M.; González-Vergara, E. Vanadium in Biological Action: Chemical, Pharmacological Aspects, and Metabolic Implications in Diabetes Mellitus. Biol. Trace Element Res. 2019, 188, 68-98. [CrossRef]

5. Crans, D.C.; Henry, L.; Cardiff, G.; Posner, B.I. Developing Vanadium as an Antidiabetic or Anticancer Drug: A Clinical and Historical Perspective. In Essential Metals in Medicine: Therapeutic Use and Toxicity of Metal Ions in the Clinic, 1st ed.; Carver, P.L., Ed.; De Gruyter: Berlin, Germany; Boston, MA, USA, 2019; pp. 203-230.

6. Rehder, D. The potentiality of vanadium in medicinal applications. Inorg. Chim. Acta 2020, 504, 119445. [CrossRef]

7. Ścibior, A.; Pietrzyk, Ł.; Plewa, Z.; Skiba, A. Vanadium: Risks and possible benefits in the light of a comprehensive overview of its pharmacotoxicological mechanisms and multi-applications with a summary of further research trends. J. Trace Elements Med. Biol. 2020, 61, 126508. [CrossRef] [PubMed]

8. Aureliano, M.; Gumerova, N.I.; Sciortino, G.; Garribba, E.; Rompel, A.; Crans, D.C. Polyoxovanadates with emerging biomedical activities. Coord. Chem. Rev. 2021, 447, 214143. [CrossRef]

9. Shechter, Y.; Goldwaser, I.; Mironchik, M.; Fridkin, M.; Gefel, D. Historic perspective and recent developments on the insulin-like actions of vanadium; towards developping vanadium-based drugs for diabetes. Coord. Chem. Rev. 2003, 237, 3-11. [CrossRef]

10. Rehder, D. Bioinorganic Vanadium Chemistry; John Wiley \& Sons Ltd.: Chichester, UK, 2010.

11. Costa Pessoa, J.; Santos, M.F.; Correia, I.; Sanna, D.; Sciortino, G.; Garribba, E. Binding of vanadium ions and complexes to proteins and enzymes in aqueous solution. Coord. Chem. Rev. 2021, 449, 214192. [CrossRef]

12. Mjos, K.D.; Orvig, C. Metallodrugs in Medicinal Inorganic Chemistry. Chem. Rev. 2014, 114, 4540-4563. [CrossRef]

13. Sanna, D.; Garribba, E. Pharmacollogically Active Vanadium Species: Distribution in Biological Media and Interaction with Molecular Targets. Curr. Med. Chem. 2021, 28, 7339-7384. [CrossRef]

14. Rangel, M.; Tamura, A.; Fukushima, C.; Sakurai, H. In Vitro study of the insulin-like action of vanadyl-pyrone and -pyridinone complexes with a $\mathrm{VO}(\mathrm{O} 4)$ coordination mode. JBIC J. Biol. Inorg. Chem. 2001, 6, 128-132. [CrossRef] [PubMed]

15. Rozzo, C.; Sanna, D.; Garribba, E.; Serra, M.; Cantara, A.; Palmieri, G.; Pisano, M. Antitumoral effect of vanadium compounds in malignant melanoma cell lines. J. Inorg. Biochem. 2017, 174, 14-24. [CrossRef] [PubMed]

16. Pisano, M.; Arru, C.; Serra, M.; Galleri, G.; Sanna, D.; Garribba, E.; Palmieri, G.; Rozzo, C. Antiproliferative activity of vanadium compounds: Effects on the major malignant melanoma molecular pathways. Metallomics 2019, 11, 1687-1699. [CrossRef] [PubMed]

17. Buglyó, P.; Kiss, T.; Kiss, E.; Sanna, D.; Garribba, E.; Micera, G. Interaction between the low molecular mass components of blood serum and the VO(IV)-DHP system (DHP =1,2-dimethyl-3-hydroxy-4(1H)-pyridinone). J. Chem. Soc. Dalton Trans. 2002, 11, 2275-2282. [CrossRef]

18. Nurchi, V.M.; Cappai, R.; Chand, K.; Chaves, S.; Gano, L.; Crisponi, G.; Peana, M.; Zoroddu, M.A.; Santos, M.A. New strong extrafunctionalizable tris(3,4-HP) and bis(3,4-HP) metal sequestering agents: Synthesis, solution and in vivo metal chelation Dalton Trans. 2019, 48, 16167-16183. [CrossRef]

19. Santos, M.; Grazina, R.; Neto, A.Q.; Cantinho, G.; Gano, L.; Patrício, L. Synthesis, chelating properties towards gallium and biological evaluation of two N-substituted 3-hydroxy-4-pyridinones. J. Inorg. Biochem. 2000, 78, 303-311. [CrossRef]

20. Gans, P.; Sabatini, A.; Vacca, A. Investigation of equilibria in solution. Determination of equilibrium constants with the HYPERQUAD suite of programs. Talanta 1996, 43, 1739-1753. [CrossRef]

21. Nurchi, V.M.; Crisponi, G.; Pivetta, T.; Donatoni, M.; Remelli, M. Potentiometric, spectrophotometric and calorimetric study on iron(III) and copper(II) complexes with 1,2-dimethyl-3-hydroxy-4-pyridinone. J. Inorg. Biochem. 2008, 102, 684-692. [CrossRef] 
22. Alderighi, L.; Gans, P.; Ienco, A.; Peters, D.; Sabatini, A.; Vacca, A. Hyperquad simulation and speciation (HySS): A utility program for the investigation of equilibria involving soluble and partially soluble species. Coord. Chem. Rev. 1999, 184, 311-318. [CrossRef]

23. Chasteen, D.N. Vanadyl(IV) EPR Spin Probes Inorganic and Biochemical Aspects. In Biological Magnetic Resonance; Berliner, L.J., Reuben, J., Eds.; Springer: Boston, MA, USA, 1981; pp. 53-119.

24. Smith, T.S.; LoBrutto, R.; Pecoraro, V.L. Paramagnetic spectroscopy of vanadyl complexes and its applications to biological systems. Coord. Chem. Rev. 2002, 228, 1-18. [CrossRef]

25. Sanna, D.; Buglyó, P.; Bíró, L.; Micera, G.; Garribba, E. Coordinating Properties of Pyrone and Pyridinone Derivatives, Tropolone and Catechol toward the $\mathrm{VO}^{2+}$ Ion: An Experimental and Computational Approach. Eur. J. Inorg. Chem. 2012, 2012, 1079-1092. [CrossRef]

26. Rangel, M.; Leite, A.; Amorim, M.J.; Garribba, E.; Micera, G.; Lodyga-Chruscinska, E. Spectroscopic and Potentiometric Characterization of Oxovanadium(IV) Complexes Formed by 3-Hydroxy-4-Pyridinones. Rationalization of the Influence of Basicity and Electronic Structure of the Ligand on the Properties of $\mathrm{V}^{\mathrm{IV}} \mathrm{O}$ Species in Aqueous Solution. Inorg. Chem. 2006, 45, 8086-8097. [CrossRef] [PubMed]

27. Berto, S.; Alladio, E.; Daniele, P.G.; Laurenti, E.; Bono, A.; Sgarlata, C.; Valora, G.; Cappai, R.; Lachowicz, J.I.; Nurchi, V.M Oxovanadium(IV) Coordination Compounds with Kojic Acid Derivatives in Aqueous Solution. Molecules 2019, $24,3768$. [CrossRef] [PubMed]

28. Cappai, R.; Crisponi, G.; Sanna, D.; Ugone, V.; Melchior, A.; Garribba, E.; Peana, M.; Zoroddu, M.A.; Nurchi, V.M. Thermodynamic Study of Oxidovanadium(IV) with Kojic Acid Derivatives: A Multi-Technique Approach. Pharmaceuticals 2021, 14, 1037. [CrossRef]

29. Smith, G.F.; McCurdy, W.H.; Diehl, H. The colorimetric determination of iron in raw and treated municipal water supplies by use of 4:7-diphenyl-1:10-phenanthroline. Analyst 1952, 77, 418-422. [CrossRef]

30. Frassineti, C.; Ghelli, S.; Gans, P.; Sabatini, A.; Moruzzi, M.S.; Vacca, A. Nuclear Magnetic Resonance as a Tool for Determining Protonation Constants of Natural Polyprotic Bases in Solution. Anal. Biochem. 1995, 231, 374-382. [CrossRef]

31. Henry, R.P.; Mitchell, P.C.H.; Prue, J.E. Hydrolysis of the oxovanadium(IV) ion and the stability of its complexes with the 1,2-dihydroxybenzenato(2-) ion. J. Chem. Soc. Dalton Trans. 1973, 1156-1159. [CrossRef]

32. Lichawska, M.E.; Bodek, K.H.; Jezierska, J.; Kufelnicki, A. Coordinative interaction of microcrystalline chitosan with oxovanadium (IV) ions in aqueous solution. Chem. Cent. J. 2014, 8, 50. [CrossRef]

33. Vilas Boas, L.F.; Costa Pessoa, J. Vanadium. In Comprehensive Coordination Chemistry: The Synthesis, Reactions, Properties E Applications of Coordination Compounds; Wilkinson, G., Gillard, R., Mc Cleverty, J.A., Eds.; Pergamon Press: Oxford, UK, 1987; pp. 453-583.

34. Willsky, G.; Goldfine, A.; Kostyniak, P.; McNeill, J.; Yang, L.; Khan, H.; Crans, D. Effect of vanadium(IV) compounds in the treatment of diabetes: In vivo and in vitro studies with vanadyl sulfate and bis(maltolato)oxovandium(IV). J. Inorg. Biochem. 2001, 85, 33-42. [CrossRef]

35. Thompson, K.H.; Liboiron, B.D.; Sun, Y.; Bellman, K.D.; Setyawati, I.A.; Patrick, B.O.; Karunaratne, V.; Rawji, G.; Wheeler, J.; Sutton, K.; et al. Preparation and characterization of vanadyl complexes with bidentate maltol-type ligands; in vivo comparisons of anti-diabetic therapeutic potential. JBIC J. Biol. Inorg. Chem. 2003, 8, 66-74. [CrossRef]

36. Thompson, K.H.; Orvig, C. Vanadium in diabetes: 100 years from Phase 0 to Phase I. J. Inorg. Biochem. 2006, 100, 1925-1935. [CrossRef] [PubMed]

37. Thompson, K.H.; Lichter, J.; LeBel, C.; Scaife, M.C.; McNeill, J.H.; Orvig, C. Vanadium treatment of type 2 diabetes: A view to the future. J. Inorg. Biochem. 2009, 103, 554-558. [CrossRef] [PubMed]

38. Zhang, S.-Q.; Zhong, X.-Y.; Chen, G.-H.; Lu, W.-L.; Zhang, Q. The anti-diabetic effects and pharmacokinetic profiles of bis(maltolato)oxovanadium in non-diabetic and diabetic rats. J. Pharm. Pharmacol. 2010, 60, 99-105. [CrossRef] [PubMed] 